\title{
Mapping of Groundwater Flow Pattern and its Quality Index based on Microbiological Parameters in Klojen District, Malang City, East Java, Indonesia
}

\author{
Veronika Yulia Permata ${ }^{1}$, Hari Siswoyo ${ }^{1}$, Riyanto Haribowo ${ }^{1}$ \\ ${ }^{1}$ Department of Water Resources Engineering, Faculty of Engineering, Universitas \\ Brawijaya, Malang, 65145, East Java, Indonesia \\ veronikayuliapermata@gmail.com
}

Received 22-03-2021; accepted 26-04-2021

\begin{abstract}
Groundwater is one source of fulfilling water needs for the Klojen district, the most populous district in Malang City. Population density affects the condition of groundwater quality because it causes pollution. The possibility of groundwater quality contamination can be identified by mapping the flow pattern and determining the quality level according to its use as drinking water. The purpose of this study is to map the groundwater quality index according to its flow pattern. Flow patterns based on groundwater-surface contours can indicate the direction of flow and the direction of pollution. The quality of groundwater according to its use as drinking water was identified using the Weighted Arithmetic Water Quality Index (WAWQI) method. Based on the research results, the research location's flow pattern generally flows from North to South. According to the flow pattern, groundwater quality is getting worse, as indicated by an increase in the index value.
\end{abstract}

Keywords: flow pattern, groundwater, mapping, water quality

\section{Introduction}

Klojen District is one of the districts in Malang City with $8.83 \mathrm{~km}^{2}$ and 101,410 people, making it the most densely populated district. The family's drinking water source in Klojen District comes from 4156 protected wells, but only 1180 wells meet the requirements [1]. Population density affects the number of sources of pollutants that affect water quality conditions and can cause various diseases, including diarrhea. In 2016, Klojen District found 2986 cases of diarrhea disease [1]. Today, water pollution is increasing, accompanied by rapid industrial development, which causes clean water on earth to become unbalanced [2]. The possibility of groundwater quality contamination can be identified by mapping the flow pattern and identifying the quality level according to its use as drinking water.

Groundwater flow patterns can indicate the direction of flow from one area to another. The determination of groundwater flow patterns is based on groundwater contour, a relationship line from

Cite this as: Permata, V. Y., Siswoyo, H., \& Haribowo, R. (2021). Mapping of Groundwater Flow Pattern and its Quality Index based on Microbiological Parameters in Klojen District, Malang City, East Java, Indonesia. Civil and Environmental Science Journal (Civense), 4(2), 106-114. doi:

https://doi.org/10.21776/ub.civense.2021.00402.1 
places with the same water level. Determination of the contour lines of the groundwater table was carried out by using the linear interpolation method. The direction of groundwater flow is determined by cutting the contour line perpendicularly $\left(90^{\circ}\right)$ from the high contour to the lower contour [3].

According to its use, the identification of groundwater quality as drinking water can be done using the Weighted Arithmetic Water Quality Index (WAWQI) method. This method has the advantage that the number of parameters used is less than all water quality parameters for a particular use and can explain groundwater suitability for human consumption [4]. This methodical approach is based on the three most common factors, that is: (1) selection of parameters that have a significant impact on water quality; (2) determining the sub-index for each parameter that changes the non-dimensional scale value of the different unit variables; (3) aggregation of sub-indices via arithmetic mean [4]. This method has been used in several studies by previous researchers in many other countries to identify groundwater quality $[5,6,7,8,9,10]$. Each previous study used different water quality parameters and guidelines. The guidelines used are following the standards of the country where each study is located. In this study, the guidelines used are based on PERMENKES RI No. 492/2010 [11], and the parameters used are parameters whose presence affects the amount of microbiology in the water.

The purpose of this research is to map the index of groundwater quality according to its flow pattern. This study's results are expected to provide information to government agencies and the community in their efforts to deal with groundwater pollution.

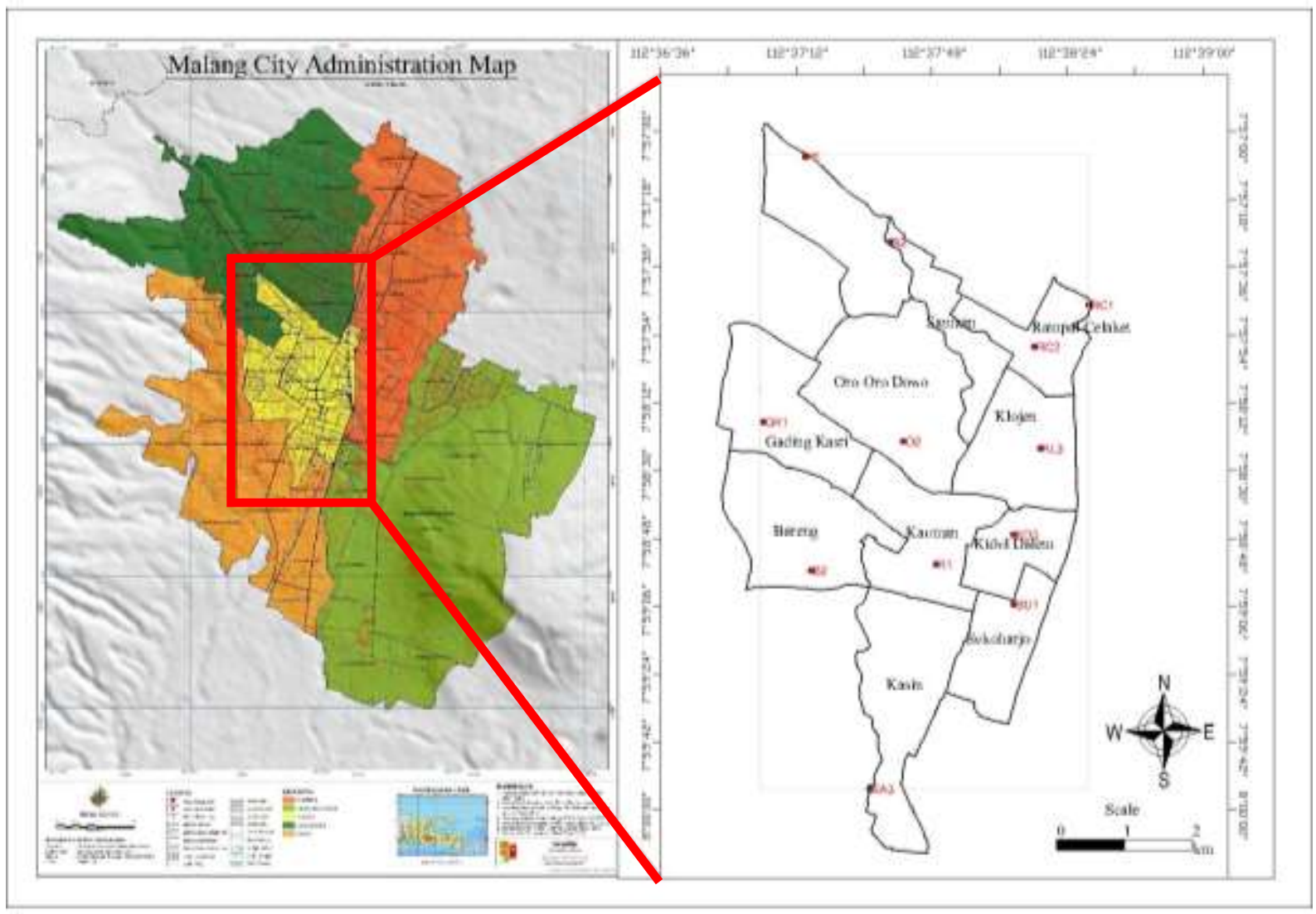

Figure 1. Location of the study area. 


\section{Materials and Methods}

\subsection{Materials}

2.1.1. Study Location. The location of the study is in Klojen District, Malang City. The groundwater wells studied were 12 wells, which are the points with the highest and lowest groundwater levels of each flow path (Figure 1).

2.1.2. Data and Equipment. The data used in this study include: (1) Map of Indonesia's Earth; (2) well location coordinates; (3) the elevation of the soil surface in the well; (4) groundwater samples. Map of the Earth of Indonesia at a scale of 1:25000 obtained from the Geospatial Information Agency website, which is used to determine the research location's boundaries. The coordinates of the resident wells are determined using the Global Positioning System (GPS) of the Garmin 73 GPS model. The groundwater level is obtained by measuring the difference between the well walls' height and the water surface's depth using a roll meter. The material used in this study is a sample of water from a resident's well. Water sampling was carried out on September 28-30, 2020. The equipment used to conduct this research included: Digital Thermometer TP 3001 model for measuring water temperature, $\mathrm{pH}$ meter model pH02 to measure the degree of acidity of water, TDS meter model TDS Testers 139 for measures total dissolved solids in water (TDS). The groundwater sample was taken using a 1-litre polyethylene bottle container and then put in a styrofoam box. The groundwater samples were then tested in the laboratory to identify the DO, BOD, COD, turbidity, total coliform, and Escherichia coli content.

\subsection{Methods}

2.2.1. Groundwater Flow Pattern Mapping. The initial step taken was a preliminary survey to determine the location of the dug wells belonging to the residents and measure the groundwater level. The coordinates of the well location and ground elevation were obtained using GPS. The measurement of the well water surface from the well's edge was carried out using a raffia rope and measured with a roll meter. The calculation to get the groundwater level is based on the following equation [12]:

where:

$$
\text { Groundwater'surface elevation }=\text { ground elevation }+\mathrm{h}-\mathrm{p}
$$

$\mathrm{h}=$ height of the well wall (m)

$\mathrm{p}=$ depth of well water $(\mathrm{m})$

After obtaining the groundwater level elevation based on Equation 1, mapping is carried out to obtain a groundwater flow pattern map. Earth map digitized to obtain a well distribution map. The well coordinate data and groundwater level elevation were then processed with the Surfer 13 computer program and integrated with the research location's boundary map to produce a groundwater flow pattern map.

2.2.2. Groundwater Quality Analysis. Groundwater sampling is carried out at the part with the highest and lowest elevations of each flow path. Groundwater sampling was carried out at 12 points evenly distributed throughout the research location and was carried out based on the Indonesian National Standard (SNI) 6989.58: 2008 Section 58: Groundwater Sampling Methods. Groundwater samples were taken from wells with a volume of 1 litre. The groundwater sample container used is made of polyethylene. Temperature, $\mathrm{pH}$, and TDS parameters were measured directly in the field because these parameters change quickly with the surrounding environmental conditions. Parameters of BOD, COD, DO, turbidity, total coliform, and Escherichia coli were tested at the Laboratory of Perum Jasa Tirta I Malang. BOD parameters were tested using the APHA 5210 B-1998 method, COD parameters were tested using the Electrometric method, DO parameters were tested using the Spectrometric method, the 
turbidity parameters were tested using the Turbid metric method, the microbiological parameters (total coliform and Escherichia coli) were tested using the Double Tube method.

The results of the content of various parameters that have been measured and tested are then analyzed. Analysis of the groundwater quality index's value was carried out using the Weighted Arithmetic Water Quality Index (WAWQI) method. The quality standard used refers to the Minister of Health Regulation No. 492 of 2010 concerning Drinking Water Quality Requirements. The steps for calculating the WAWQI method are as follows [5]:

$$
\begin{gathered}
K=1 /\left[\sum_{n=1}^{n} \frac{1}{v s}\right] \\
W=\frac{K}{v s}\left[\sum_{n=1}^{n} \frac{1}{v s}\right] \\
q=\frac{(v a-v i)}{(v s-v i)} \times 100\left[\sum_{n=1}^{n} \frac{1}{v s}\right] \\
W Q I=\text { Antilog }\left(\sum_{n=1}^{n} W n \log q n\right)\left[\sum_{n=1}^{n} \frac{1}{v s}\right]
\end{gathered}
$$

Where:

$\mathrm{W}=$ weighting factor

$\mathrm{K} \quad=$ Constat Proportionality

$\mathrm{q}=$ Quality rating

va $=$ laboratory test value

vi = ideal value of each water quality parameter (for $\mathrm{pH}=7$, for other parameters $=0$ )

vs $=$ standard value of each water quality parameter

WQI = Water Quality Index

The rating of water quality according to this WQI is given in Table 1 [5].

Table 1. Class Classification Based on WAWQI

\begin{tabular}{ccc}
\hline WQI Value & Rating of Water Quality & Grading \\
\hline $\mathbf{0}-\mathbf{2 5}$ & Excellent & $\mathrm{A}$ \\
$\mathbf{2 6}-\mathbf{5 0}$ & Good & $\mathrm{B}$ \\
$\mathbf{5 1}-\mathbf{7 5}$ & Poor & $\mathrm{C}$ \\
$\mathbf{7 6}-\mathbf{1 0 0}$ & Very Poor & D \\
$>\mathbf{1 0 0}$ & Unsuitable for drinking purpose & E \\
\hline
\end{tabular}

The groundwater quality index value was then mapped using the Surfer 13 computer program and integrated with the flow pattern map to produce a map. The groundwater flow path, integrated with the quality index value is used to determine the relationship between the two and determine pollution movement. In calculating the water quality index value using the Weighted Arithmetic Water Quality Index method, the coliform and Escherichia coli parameters cannot be included in the formula because Indonesia has a standard value for this parameter 0 . Dividing by 0 results in an undefined value. DO, BOD, and COD parameters also cannot be used in the analysis of water quality index values because they are not included in the parameters of drinking water quality requirements according to the Indonesian Minister of Health Regulation No. 492/2010. The parameters used in calculating the index value are $\mathrm{pH}$, temperature, TDS, and turbidity.

The parameters used in calculating the index value are then analyzed for their correlation with other parameters (DO, COD, BOD, total coliform, and Escherichia coli). The formula for the linear correlation coefficient ( $r$ ) is as follows: 
where:

$$
r=\frac{\sum_{i=1}^{n}\left(x_{i}-\bar{x}\right) \cdot\left(y_{i}-\bar{y}\right)}{\sqrt{\left[\sum_{i=1}^{n}\left(x_{i}-\bar{x}\right)^{2}\right] \cdot\left[\sum_{i=1}^{n}(y-\bar{y})^{2}\right]}}
$$

$-\mathrm{x} \quad=$ mean of $\mathrm{xi}$

$-\mathrm{y} \quad=$ mean of $\mathrm{yi}$

$\mathrm{N} \quad=$ the amount of data from the $\mathrm{x}$ and $\mathrm{y}$ variable pairs

The correlation test was carried out having two hypotheses to determine the correlation. The hypothesis $\mathrm{H} 0$ is the correlation coefficient of 0 , or there is no correlation between the two things being compared. Hypothesis $\mathrm{H} 1$ is that the correlation coefficient is not equal to 0 or a possible correlation between the two. Hypothesis testing is done by calculating the $t$ value with the following formula:

$$
t=\frac{|r| \times \sqrt{n-2}}{\sqrt{1-r^{2}}}
$$

The $t$ count value is compared with the critical value of tcr from the table for degrees of freedom $\mathrm{v}=$ $\mathrm{n}-2$ and $\alpha$ (level of significance) $=5 \%$. If $\mathrm{t}<\mathrm{tcr}$, then $\mathrm{H} 0$ is accepted; otherwise, $\mathrm{H} 0$ is rejected [13].

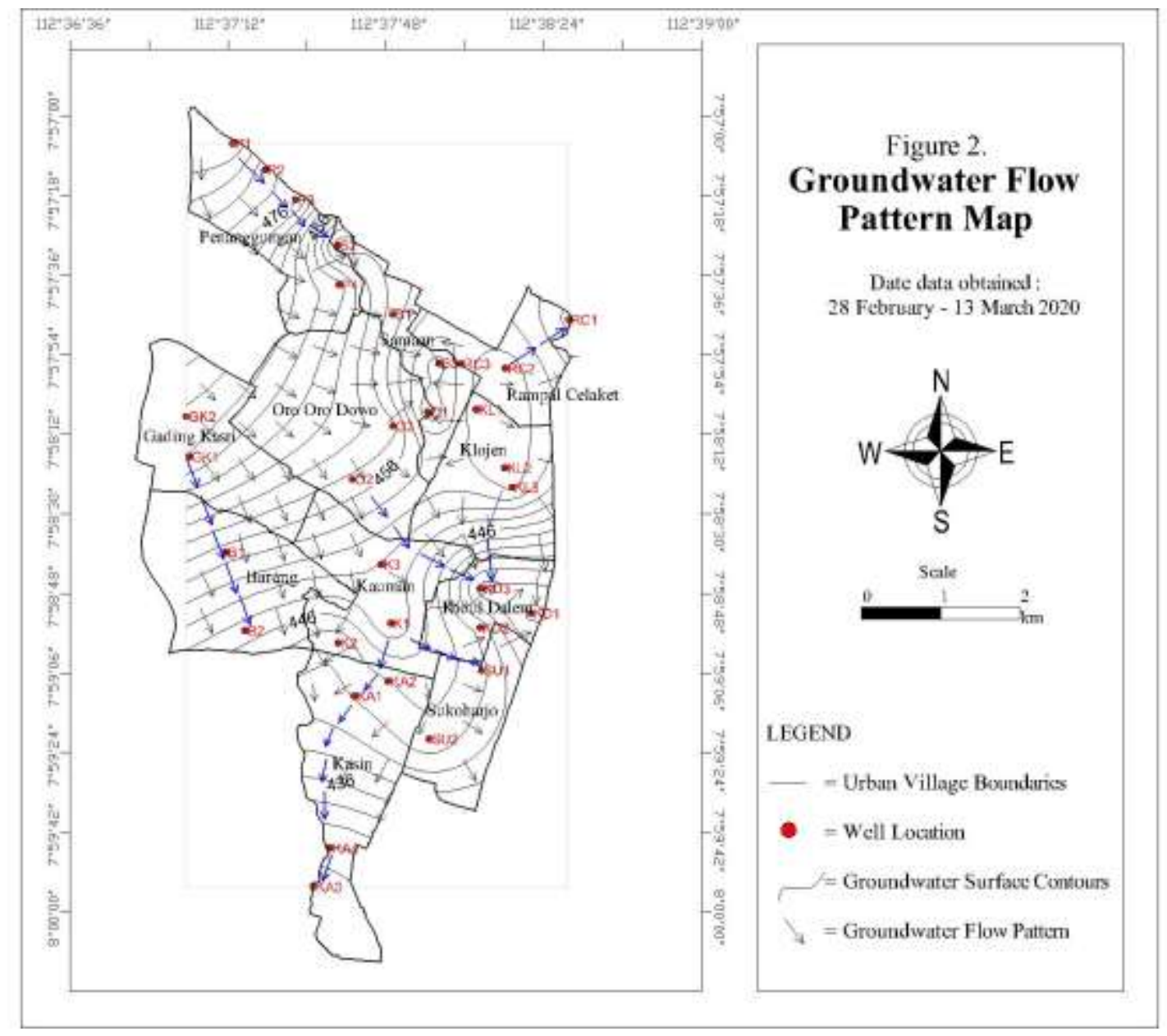

Figure 2. Groundwater flow pattern map

\section{Results and Discussion}

A groundwater flow pattern map is generated based on the depiction of groundwater-surface contours (Figure 2). Based on the flow pattern map that has been produced, groundwater flows from high elevation to low. There are two paths flow from the North to the South, namely the KL3 - KD3 path and 
the $\mathrm{O} 2$ - KD3 path; one path that flows from the North West to the Southeast, namely the P1 - P2 - P3 S2 path; one path that flows from the Southwest to the Northeast, namely the RC2 - RC1 path; one path that flows from the North to the Southeast, namely the GK1 - B1 - B2 path; one path that flows from the North to the Southwest, namely the K1 - KA2 - KA1 - KA4 - KA3 path; one path which flows from the Northwest to the East, namely the K1 - SU1 path. According to the groundwater level contour, the groundwater flow pattern in Klojen District generally flows from North to South.

Based on the resulting groundwater flow pattern, groundwater sampling was then carried out at 12 wells points. Groundwater quality with temperature, TDS and $\mathrm{pH}$ parameters is measured directly in the field using a digital thermometer, TDS meter and $\mathrm{pH}$ meter. The parameters included in calculating the water quality index value are $\mathrm{pH}$, temperature, TDS, and turbidity. The results of the calculation of the water quality index value are tabulated in Table 2 .

Table 2. Results of Water Quality Index Value Calculation

\begin{tabular}{rllll}
\hline No. & $\begin{array}{l}\text { Well } \\
\text { Code }\end{array}$ & Urban Village & WQI & Rating \\
\hline 1 & P1 & Penanggungan & 53.14 & Poor \\
2 & KL3 & Klojen & 50.66 & Good \\
3 & KA3 & Kasin & 71.97 & Poor \\
4 & O2 & Oro - oro Dowo & 68.88 & Poor \\
5 & S2 & Samaan & 60.03 & Poor \\
6 & RC2 & Rampal Celaket & 57.76 & Poor \\
7 & RC1 & Rampal Celaket & 50.24 & Good \\
8 & KD3 & Kidul dalem & 58.80 & Poor \\
9 & SU1 & Sukoharjo & 56.64 & Poor \\
10 & B2 & Bareng & 54.37 & Poor \\
11 & K1 & Kauman & 36.02 & Good \\
12 & GK1 & Gading Kasri & 54.34 & Poor \\
\hline
\end{tabular}

The index value of groundwater quality for drinking water with $\mathrm{pH}$, temperature, TDS, and turbidity at the study site ranged from 36.02 to 71.97 , which are in two categories: good quality (26-50) and poor (51-75). Based on the groundwater quality index value, the three urban villages with "Good" quality include Klojen, Rampal Celaket southern area, and Kauman. Meanwhile, nine urban villages with "Poor" quality include Penanggungan, Kasin, Oro-Oro Dowo, Samaan, Rampal Celaket northern area, Kidul Dalem, Sukoharjo, Bareng, and Gading Kasri. Groundwater with "Poor" quality means that it is of poor quality but can still be used for drinking water is only recommended.

The best water quality index value is in the K1 well in Kauman Urban Village, which is 36.02 or the quality level of "Good" and the only well that has a $\mathrm{pH}$ value according to the quality standard of 6.734 or is very close to neutral. The turbidity value of well K1 is $1.1 \mathrm{NTU}$, indicating that the water in the well is clear. The $\mathrm{pH}$ and turbidity values are very influential in calculating water quality index values because they have a considerable weight. The distribution of the water quality index values according to the flow path is depicted in Figure 3.

The decline in water quality occurred on path 1 that connecting wells P1 - P2 - P3 - S2, marked by an increase in the index value (from 53.14 to 60.03). Similar conditions also occur on path 3 connecting wells GK1 - B1 - B2 with an increase in the index value from 53.34 to 54.37. The index value of paths 1 and 3 are still in the same classification class, namely "Poor" quality.

A very significant decrease in water quality occurred on paths 5 and 6 . It was indicated by an increase in the water quality index value on these paths. Path 5 connects the wells K1 - KA2 - KA1 - KA4 - KA3, flowing from the North to the Southwest. As shown in Figure 3, the area with a high groundwater level, 
namely K1 well is included in the "Good" category (index value 36.02) and the area with a low groundwater level, namely KA3 well is included in the "Poor" category (value index 71.97). Similar conditions also occur on Path 6, which connects wells K1 - SU1 and flows from the Northwest to the East. The area with a high groundwater level, namely K1, is included in the "Good" category (index value 36.02) and the part of the area with a low groundwater level, namely SU1 well, is included in the "Poor" category (index value 56.64). Decreasing water quality also occurs on Path 4, which connects KL3 - KD3 that flow from North to South. The area with high groundwater level, namely KL3 is included in the "Good" category (index value 50.66) and the area with a low groundwater level, namely KD3 well, is included in the "Poor" category (index value 58.80).

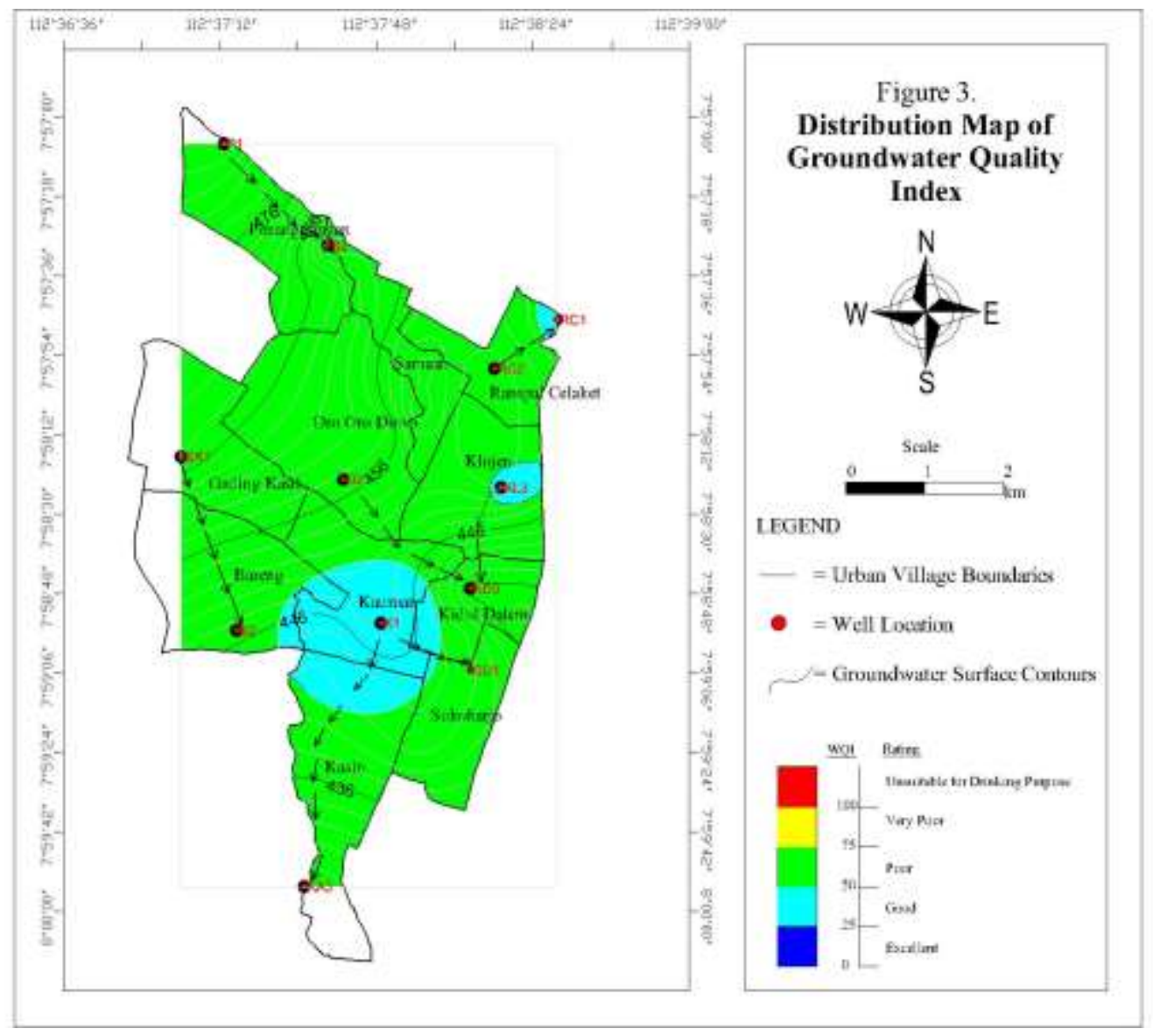

Figure 3. Distribution map of groundwater quality index

An increase in groundwater quality, marked by a decrease in the water quality index's value, occurred on Path 2. Path 2 connecting RC2 - RC1 flowing from the Southwest to the Northeast experienced a decrease in the value of the water quality index, namely from the "Poor" category (index value 57.76) becomes "Good" (index value 50.24). This condition also occurs on Path 7, which connects wells O2 KD3 with an index value of 68.99 to 58.88 so that they are still in the same classification class, namely "Poor" quality.

The presence or absence of bacteria determines the quality of water for drinking water or human consumption. Based on PERMENKES RI No. 492/2010, microbiological content should not be present in drinking water. The microbiological conditions at the study sites are shown in Figure 4.

The lowest microbiological content was in the RC2 well (total coliform $7 \mathrm{MPN} / 100 \mathrm{ml}$ and Escherichia coli $4 \mathrm{MPN} / 100 \mathrm{ml}$ ), which had excellent environmental conditions because it was far from pollutant sources and separated from the toilet. The disposal of liquid waste in the RC2 well is 50 meters 
away. Meanwhile, the highest microbiological content was in the $\mathrm{O}_{2}$ well (total coliform 265 MPN/100ml and Escherichia coli $84 \mathrm{MPN} / 100 \mathrm{ml}$ ). The $\mathrm{O}_{2}$ well as poor environmental conditions because it is 1 meter near the toilet, 20 meters away from the septic tank, and is in a densely populated settlement.

The mismatch between the water quality index's value and the amount of microbiology occurred in Kauman Urban Village (well K1). K1 had the lowest index of 36.02 and the highest amount of microbiology of $349 \mathrm{MPN} / 100 \mathrm{ml}$. The liquid waste from the house is discharged directly into the river without being accommodated by the septic tank, the distance between the well and the pollutant source is only 10 meters. Microbiology is much influenced by the concentration of hydrogen with an optimum $\mathrm{pH}$ of $6.0-8.0$ [14]. The $\mathrm{pH}$ value in the $\mathrm{K} 1$ well is 6.734 , allowing growth and microbiological development in the well, but this $\mathrm{pH}$ value is a good condition if intended as drinking water. Considering that $\mathrm{pH}$ is the parameter with the most significant weight in assessing the water quality index, the index value results are also good. To reduce the amount of microbiology necessary to carry out a drinking water treatment process by heating or boiling.

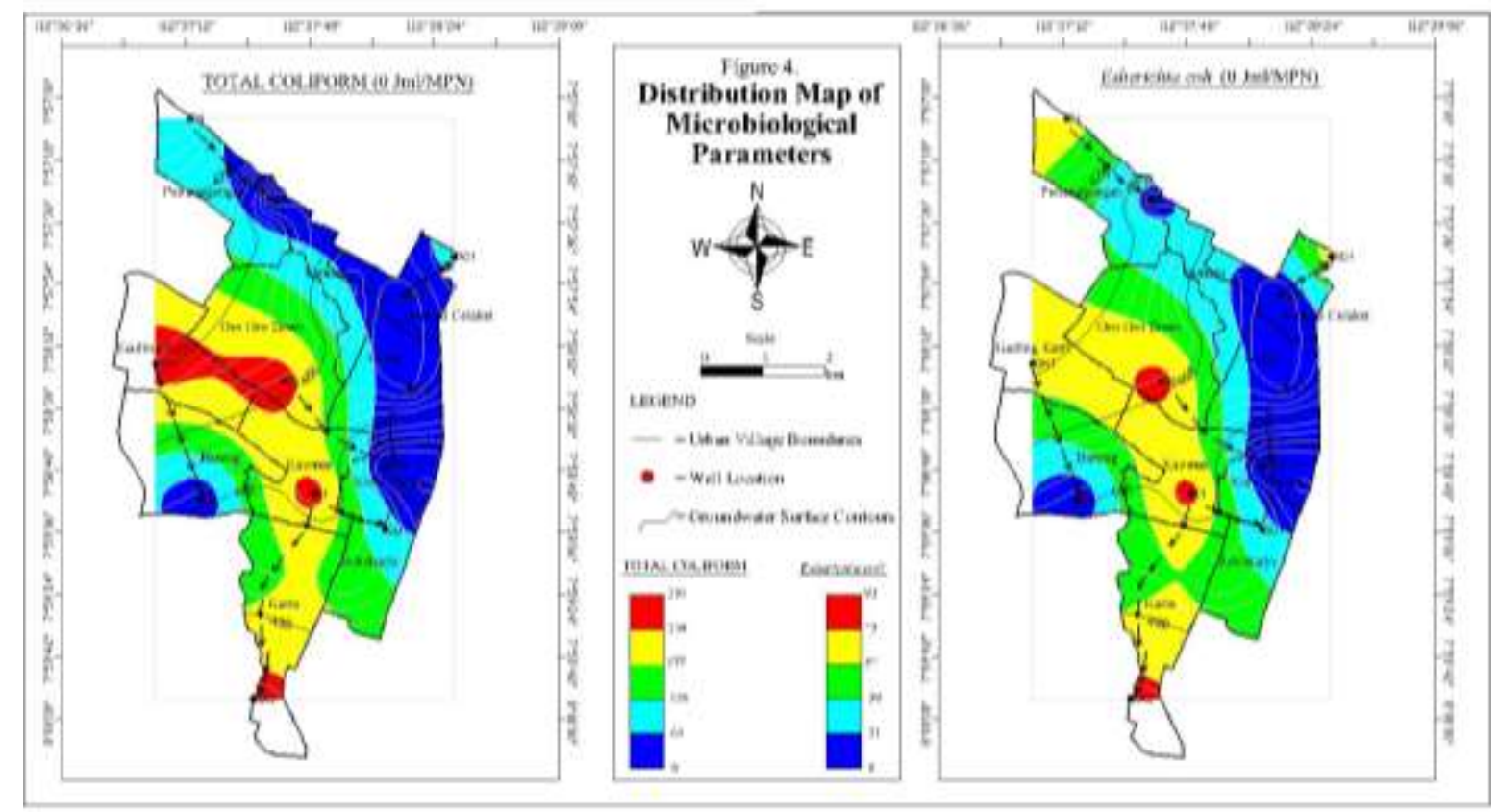

Figure 4. Distribution map of microbiological parameters

The water quality index value then tested for correlation with other parameters (DO, BOD, COD, Total Coliform, and Escherichia coli. This correlation is to determine the closeness of the relationship between these parameters.

Table 3. Correlation Test Analysis

\begin{tabular}{cccccc}
\hline \multicolumn{2}{c}{ Simple Correlation Test } & $\mathrm{r}$ & $\mathrm{t}$ count & $\mathrm{t}$ table & $\mathrm{H} 0$ \\
\hline & DO & 0.496 & 1.807 & & ACCEPTED \\
Water Quality & BOD & -0.195 & 0.627 & & ACCEPTED \\
Index Value & COD & 0.479 & 1.725 & 2.23 & ACCEPTED \\
& Total Coliform & 0.104 & 0.330 & & ACCEPTED \\
& Escherichia coli & 0.026 & 0.083 & & ACCEPTED \\
\hline
\end{tabular}

Analysis of the correlation between the value of the water quality index and other parameters resulted in the conclusion that no correlation or relationship influenced each other. This conclusion is obtained from testing the significance to test the hypothesis, which is done by comparing the values of $t$ tables 
and $t$ arithmetic. If the $t$ table is smaller than the $t$ count, then the hypothesis is accepted because the $t$ count value is in the receiving area, so there is no relationship between the index value and all other parameters.

\section{Conclusions}

The groundwater flow pattern in the research location generally flows from the northern part (Penanggungan Urban Village), which has the highest groundwater level $(+485.9 \mathrm{~m}$ asl) to the South (Kasin Urban Village) with the lowest groundwater level $(+426.2 \mathrm{~m}$ asl). The groundwater quality in the study location based on its flow pattern from North to South is getting worse. Groundwater quality decrease can be shown based on the WQI value and the content of microbiological parameters, wherein the northernmost area (Penanggungan Urban Village), the WQI value is 53.14 with a microbiological amount of $151 \mathrm{MPN} / 100 \mathrm{ml}$ (consisting of $84 \mathrm{MPN} / 100 \mathrm{ml}$ coliform and $67 \mathrm{MPN} / 100 \mathrm{ml}$ Escherichia coli), while in the South area (Kasin Urban Village) the WQI value was 71.97 with a microbiological number of $349 \mathrm{MPN} / 100 \mathrm{ml}$ (consisting of $265 \mathrm{MPN} / 100 \mathrm{ml}$ coliform and $84 \mathrm{MPN} / 100 \mathrm{ml}$ Escherichia coli). To prevent groundwater contamination, government agencies conduct regular quality monitoring and the community limits activities that can make the high risk of groundwater contamination.

\section{References}

[1] A. T. R. Nuswantari, Buku Putih Sanitasi Kota Malang Tahun 2014. Malang, Pemerintah Kota Malang, 2014.

[2] R. Haribowo, M, Yoshimura, M, Sekine, K, Yamamoto, T, Higuchi, A, Kanno, "Behavior of toxicity in river basins dominated by residential areas". Contemporary Engineering Sciences, 10(7), pp. 305-315, 2017.

[3] Adji, Nugroho, dan Santosa., Karakteristik Akuifer dan Potensi Airtanah Graben Bantul, Gajah Mada University Press, 2014.

[4] T. Shweta, S. Bhavtosh, S. Prashat, D. Rajendra., "Water Quality Assessment in Terms of Water Quality Index”, American Journal of Water Resources Vol. 1 No. 3: 34 -38, 2013.

[5] S. Kumar, "Assessment of Ground Water Quality Using Water Quality Index", International Journal of Innovative Research in Advanced Engineering, Issue 3, Vol. 2, 2015.

[6] S. Harsan et al, "Assessment of Water Quality Index of Groundwater Quality in Chunnakam and Jaffna Town, Sri Lanka", Vingnanam Journal of Science 13:1-2, 2017.

[7] D. Chandra., S. Satist., S. Asadi., and S. Raju., "Estimation of Water Quality Index by Weighted Arithmetic Water Quality Index Method: a Model Study", International Journal of Civil Engineering and Technology 8.4: 1215-1222, 2017.

[8] Ewaid, Sallam, Hussein, and S. Abed., "Water Quality Index For Al-Gharraf River, Southern Iraq", The Egyptian Journal of Aquatic Research 43.2 : 117-122, 2017.

[9] Panday et al, "Assessment Of Water Quality Of River Narmada Using Water Guality Index (WQI)", Iaetsd Journal for Advandce Research in Applied Science Vol. 5, 2018.

[10] H. Siswoyo., D. Rifki., "Pemetaan Pola Aliran dan Indeks Kualitas Air Tanah di Kecamatan Tanggulangin Kabupaten Sidoarjo", Jurnal Mahasiswa Jurusan Teknik Pengairan 2.1: 7, 2018.

[11] Peraturan Menteri Kesehatan Republik Indonesia, Persyaratan Kualitas Air Minum No 492 Tahun 2010., Jakarta: Percetakan Negara, 2010.

[12] E. A. Amah, M. A. Agbebia, "Determination Of Groundwater Flow Direction In Ekintae Limestone Quarry Near Mfamosing, South-Eastern, Nigeria," International Journal of Geology, Agriculture and Environmental Sciences., Vol - 3, Issue - 6, December 2015.

[13] L. Montarcih, Statistika Hidrologi Terapan untuk Teknik Pengairan. Malang: Penerbit Citra, 2014.

[14] Mudatsir, "Faktor - Faktor yang Mempengaruhi Kehidupan Mikroba Dalam Air", Jurnal Kedokteran Syiah Kuala, Vol.7, No.1, 2007. 